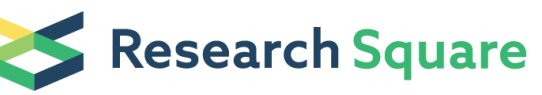 \\ Preprints are preliminary reports that have not undergone peer review. \\ They should not be considered conclusive, used to inform clinical practice, \\ or referenced by the media as validated information.
}

\section{Factors Associated With Virological Suppression of HIV Viral Load in Patients on Antiretroviral Therapy in Conakry, Guinea}

\section{Alimou camara ( $\sim$ alimou.4camara@gmail.com )}

Teacher and researcher at Gamal Abdel Nasser University in Conakry https://orcid.org/0000-00027122-1885

\section{Penda Maladho Diallo}

Teacher and researcher at Gamal Abdel Nasser University in Conakry

\section{Mamadou Bobo Diallo}

Teacher and researcher at Gamal Abdel Nasser University in Conakry

\section{Talla Nioké}

Teacher and researcher at Gamal Abdel Nasser University in Conakry

\section{Adama Cissé}

Teacher and researcher at Gamal Abdel Nasser University in Conakry

\section{Mamadou Alpha Sylla}

Teacher and researcher at Gamal Abdel Nasser University in Conakry

\section{Gobounet Lamah}

Teacher and researcher at Gamal Abdel Nasser University in Conakry

Mamady Diakité

Teacher and researcher at Gamal Abdel Nasser University in Conakry Amadou Sadio Bah

Teacher and researcher at Gamal Abdel Nasser University in Conakry Mamadou Bhoye Keita

Teacher and researcher at Gamal Abdel Nasser University in Conakry

\section{Alpha Kabinet Keita}

Teacher and researcher at Gamal Abdel Nasser University in Conakry

\section{Mamoudou Conde}

Teacher and researcher at Gamal Abdel Nasser University in Conakry

\section{Kaba Kourouma}

Teacher and researcher at Gamal Abdel Nasser University in Conakry

\section{Robert camara}

Teacher and researcher at Gamal Abdel Nasser University in Conakry

\section{Youssouf Koita}

Teacher and researcher at Gamal Abdel Nasser University in Conakry 


\section{Fode Bangaly Magassouba}

Teacher and researcher at Gamal Abdel Nasser University in Conakry Alioune camara

Teacher and researcher at Gamal Abdel Nasser University in Conakry Abdoulaye Abdoulaye TOURE

Teacher and researcher at Gamal Abdel Nasser University in Conakry

\section{Research}

Keywords: Factors associated, Virological suppression, Antiretroviral therapy, Conakry, Guinee

Posted Date: September 15th, 2021

DOl: https://doi.org/10.21203/rs.3.rs-885619/v1

License: (c) (i) This work is licensed under a Creative Commons Attribution 4.0 International License.

Read Full License 


\section{Abstract}

\section{Background}

The viral load has become an indispensable tool in evaluating antiretroviral therapy (ART) in people living with HIV / AIDS. This study aimed to assess virological suppression among in people living with HIV / AIDS on antiretroviral therapy in Guinea.

\section{Methods}

This was a descriptive cross-sectional study of more than three years that involved adult HIV-positive patients treated in different sites in Conakry. A total of 9815 viral load data were collected. The viral load was quantified by the Generic Biocentric technique and the detection threshold set at $350 \mathrm{copies} / \mathrm{ml}$. Statistical analyses were performed by R software version R4.0.3..

\section{Results}

A total of 9815 viral load data collected at the national public health laboratory were analysed. The sample was dominated by women $(72 \%)$, with an average age of $29[29,39]$. Of these, $6,706(68 \%)$ of HIVpositive people on ART had viral load suppression. The univaried analysis showed that women were $22 \%$ more likely to have VL suppression ( $p$-value $<0.001$ ) moreover, the chance for all HIV-positive people on treatment to achieve viral load suppression was related to the length of treatment.

Conclusion

the results of this study show viral load suppression greater than $68 \%$. The length of antiretroviral therapy, female gender, and advancing age of PLHIV were all favourable to VL suppression.

\section{Introduction}

About forty years since discovering the Human Immunodeficiency Virus (HIV), nearly 35 million people have died, and about 36 million people live with the dise(1). With the support of the Global Fund to Fight HIV, Malaria and Tuberculosis combined with a grant from the Guinean government, antiretroviral treatment (ART) was made accessible in 2007(2). Until 2017, Guinea had 142 sites integrated into the care of people living with HIV/AIDS (PLHIV), with only 86 functional (3). According to the latest Demographic and Health Survey (DHS) in 2018, HIV prevalence in Guinea is estimated at 1.5\% (4).

Since the United Nations AIDS Programme (UNAIDS) set its target of three out of 90 by the end of 2020, viral load has become the essential tool for assessing the success or otherwise of ART in PLHIV (Kitchen et al., 2020; UNAIDS, 2014). It also allows biological monitoring of these people (5)

The first viral load (VL) tests in Guinea among PLHIV began in 2006 on a cohort of patients followed by the NGO DREAM (an Italian Christian organisation involved in caring for people living with HIV/AIDS). It 
was not until 2013 that viral load testing was made available to patients in the active file in Conakry (4).

According to a global progress report on the fight against AIDS in 2019, Guinea has an active file of 61897 people on ART, of whom 26213 have received a viral load test, i.e., $22 \%$ of PLWHA. The cascade of care was $52 \%$ for screening and treatment and $22 \%$ for viral load. About the three UNAIDS 90 s, the situation in Guinea is as follows $52 \%$ for the 1 st $90,99 \%$ for the 2 nd 90 and $42 \%$ for the 3rd $90(6)$.

Viral load testing is a key indicator for assessing ART success and diagnosing drug resistance in people living with HIV/AIDS on antiretroviral therapy(7).

Even though the authorities and its partners have multiple efforts, notably the Global Fund, Guinea struggles to reach the third 90 of the UNAIDS targets. Several piecemeal studies have described viral load testing in one category of people living with $\operatorname{HIV/AIDS}(6,7)$. No study has focused on many patients receiving $V L$ and the factors associated with its suppression. To address this study, we ask what proportions of people living with HIV/AIDS achieve viral load suppression in the Conakry care sites. What are the factors associated with viral load suppression among PLHIV in Conakry?

Knowing this proportion of PLHIV achieving VL suppression and its associated factors could help develop new strategies for achieving the third 90 of the UNAIDS target.

The objective of this study was to investigate the frequency and factors associated with viral load suppression among PLHIV in the care sites in Conakry.

\section{Methods}

Setting and study design

Conakry, the capital of the Republic of Guinea, covers an area of $450 \mathrm{~km} 2$ and is populated by nearly 2 300000 inhabitants, meaning a quarter of the Guinean population (8). Conakry is reported to have 22 sites for the care of patients living with HIV/AIDS(2). The National Public Health Laboratory (LNSP) ensures the biological and virological monitoring of all these patients under ARV in the care sites in Conakry outside the Donka National Hospital (3). These were four communal medical centres in Conakry, the Ignace Deen National Hospital, the ASFEGMASSI Outpatient Treatment Centre, the Armed Forces Health Service, the Mother and Child Centre, Bernay Fotoba, of the Medical Center of the campagny of Bauxites of Guinea some private clinics and six health centres. These sites provide care for a large cohort of PLHIV whose virological follow-up is ensured by the National Institute of Public Health.

Study population

The study population consisted of patients living with HIV/AIDS (PLWHA), followed up at care sites affiliated with the National Institute of Public Health and receiving viral load testing between January 2018 and June 2021. Patients with incomplete information were excluded from the study. 
The molecular biology unit has a database from which we extracted data from January 2018 to June 2021. These data concerned socio-demographic characteristics (age, sex and residence), the reason for requesting a viral load test, the use of ARVs, the date of initiation of treatment, the dates of sampling and analysis, the treatment lines (first, second and third) and treatment regimens as well as the interpretation of the viral load results. According to Guinea's national HIV management protocol, the first line consists of $3 T C+T D F+E F V$, the second line $3 T C+T D F+L P V / r$ and the third line various combinations sometimes based on 2INRT+ Darunavir/Ritonavir or Raltegravir + Etranvirine $(9,10)$. Patients with a viral load of 390 copies/ml or less were considered virologically suppressed.

\section{Laboratory techniques}

RNA was isolated from plasma by an automated method, and amplification was performed as described by the RT-PCR principle using the HIV generic biocentric (11). The detection limit was set at $390 \mathrm{copies} / \mu \mathrm{l}$ for a $250 \mu$ l plasma sample.

Data analysis

The data description was done by calculating proportions for categorical variables and means for quantitative variables. Comparisons were made using the Chi-2 or Fischer test for categorical variables and Student's t-test for quantitative variables. Factors associated with virological suppression were analysed by univariate or multivariate logistic regression. In multivariate analysis, only variables with a pvalue $\leq 0.20$ were used in the multivariate model. The Hosmer-Lemeshow test was used-analysis of the accuracy of the model. The risk of suppression was estimated by calculating the Odds Ratio (OR), followed by its $95 \%$ confidence interval. The significance level was set at $5 \%$. All statistical analyses were performed using R software version R4.0.3.

\section{Ethical considerations}

As the collection was done retrospectively on routine data, consent was not sought. However, each participant has a unique national code, and the staff in charge of collecting the samples maintained confidentiality. The study was approved by the research committee of the public health department of Gamal Abdel Nasser University in Conakry.

\section{Results}

A total of 10602 patients were tested for viral load, of which 787 were excluded. Thus, data from 9815 patients were included, i.e., $92.57 \%$ (Fig. 1).

Among the 9815 patients included in our study, all were HIV1 positive with a mean age of 29 (29.39) and a female predominance $(72 \%)$. Nearly $98 \%$ of our patients were on first-line antiretroviral therapy. The reason for requesting a viral load test was dominated by routine check-ups $(88 \%)$. Forty-two percent of 
patients had treatment duration of $0-1$ year, followed by those with a duration of $1-5$ years. Viral load suppression was observed in $68.32 \%$ of patients (Table 1 ).

Univariate analysis of the data showed that women were more likely to have a suppressed viral load, with $95 \mathrm{Cl} 1.22(1.11 ; 1.34)$. Patients on the second line of treatment were $23 \%$ less likely to have a suppressed viral load. The longer the treatment, the greater the chance of having a suppressed viral load 1.08 [0.98; 1.19]. It also showed that the advancing age of patients was favourable to viral load suppression (table 2).

Multivariate analysis of the data showed that duration of treatment and female gender were independently related to viral load suppression, $95 \mathrm{Cl}[0.85(0.75,0.95)]<0.005$ (table 3 ).

Table 1: Sociodemographic characteristics of patients receiving viral load between January 2018 and June 2021 at the National Institute of Public Health 


\begin{tabular}{|c|c|}
\hline Characteristic & $N=9,815^{1}$ \\
\hline \multicolumn{2}{|l|}{ Gender } \\
\hline Female & $7,067(72 \%)$ \\
\hline Male & $2,748(28 \%)$ \\
\hline \multicolumn{2}{|c|}{ Reason. Sample collection } \\
\hline VL-reinforcement obs & $161(1.6 \%)$ \\
\hline VL-6months later & $572(5.8 \%)$ \\
\hline VL-Follow-up check & $8,614(88 \%)$ \\
\hline VL-Search & $148(1.5 \%)$ \\
\hline VL-PTME & $5(<0.1 \%)$ \\
\hline VL-initiation & $315(3.2 \%)$ \\
\hline \multicolumn{2}{|c|}{ Under Antiretroviral treatment. } \\
\hline No & $27(0.3 \%)$ \\
\hline Yes & $9,788(100 \%)$ \\
\hline \multicolumn{2}{|l|}{ Line. Treatment } \\
\hline 1 stline & $9,596(98 \%)$ \\
\hline 2ndline & $219(2.2 \%)$ \\
\hline \multicolumn{2}{|l|}{ Interpretation.VL } \\
\hline VL-Not deletion & $3,109(32 \%)$ \\
\hline VL-Deletion & $6,706(68 \%)$ \\
\hline Age (average) & $29(29,39)$ \\
\hline \multicolumn{2}{|l|}{ Duration of treatment } \\
\hline$[0,1]$ & $4,158(42 \%)$ \\
\hline$(1,5]$ & $3,548(36 \%)$ \\
\hline$(5,11]$ & $2,109(21 \%)$ \\
\hline \multicolumn{2}{|l|}{ Age at initiation (years) } \\
\hline [0-20] & $553(5.6 \%)$ \\
\hline$(20-40]$ & $7,036(72 \%)$ \\
\hline$(40-60]$ & $2,010(20 \%)$ \\
\hline
\end{tabular}




\begin{tabular}{|ll|}
\hline Characteristic & $\mathbf{N}=9,815^{1}$ \\
\hline$(60-84]$ & $216(2.2 \%)$ \\
\hline${ }^{1} \mathrm{n}(\%) ;$ Median (IQR) & \\
\hline
\end{tabular}

Table 2: Univariate analysis of factors associated with viral load suppression in patients receiving viral load at the National Institute of Public Health 


\section{$N=3109$}

$N=6706$

Gender:

Male

Female

Reason for collection

VL-observation

VL -6 months

VL -Follow-up

VL -Research

VL -PTME

V-initiation

UnderARV treatment

No

Yes

Treatment line

$1^{\text {st }}$ line

$2^{\text {nd }}$ line
956 (30.7\%)

2153 (69.3\%)
$1792(26.7 \%)$

4914 (73.3\%)
Ref.

$1.22[1.11 ; 1.34] \quad<0.001$

Ref.

$70(1.04 \%) \quad$ Ref. Ref.

$382(5.70 \%) \quad 2.61[1.83 ; 3.74] \quad<0.001$

$6003(89.5 \%) \quad 2.99[2.18 ; 4.11] \quad<0.001$

$65(0.97 \%) \quad 1.02[0.65 ; 1.60] \quad 0.938$

$2(0.03 \%) \quad 0.89[0.10 ; 5.98] \quad 0.902$

$3(0.10 \%)$

$184(2.74 \%)$

$1.82[1.24 ; 2.68]$

0.002

$8(0.26 \%)$

$3101(99.7 \%)$

$3020(97.1 \%)$

$89(2.86 \%)$
$19(0.28 \%)$

$6687(99.7 \%)$
Ref.

$0.92[0.37 ; 2.04]$

0.841

Duree treat:

\begin{tabular}{lllcc}
\hline$[0,1]$ & $1385(44.5 \%)$ & $2773(41.4 \%)$ & Ref. & Ref. \\
\hline$(1,5]$ & $1120(36.0 \%)$ & $2428(36.2 \%)$ & $1.08[0.98 ; 1.19]$ & 0.104 \\
\hline$(5,11]$ & $604(19.4 \%)$ & $1505(22.4 \%)$ & $1.24[1.11 ; 1.40]$ & $<0.001$
\end{tabular}

Age1:

\begin{tabular}{lllcc}
\hline$[0,20]$ & $230(7.40 \%)$ & $323(4.82 \%)$ & Ref. & Ref. \\
\hline$(20,40]$ & $2304(74.1 \%)$ & $4732(70.6 \%)$ & $1.46[1.23 ; 1.74]$ & $<0.001$ \\
\hline$(40,60]$ & $520(16.7 \%)$ & $1490(22.2 \%)$ & $2.04[1.68 ; 2.48]$ & $<0.001$ \\
\hline$(60,84]$ & $55(1.77 \%)$ & $161(2.40 \%)$ & $2.08[1.47 ; 2.97]$ & $<0.001$
\end{tabular}


Table 3: Multivariate analysis of factors associated with viral load suppression in patients receiving viral load at the National Institute of Public Health 


\begin{tabular}{|c|c|c|c|}
\hline Characteristic & $\mathrm{OR}^{1}$ & $95 \% \mathrm{Cl}^{1}$ & p-value \\
\hline \multicolumn{4}{|l|}{ Gender } \\
\hline Male & - & - & \\
\hline Female & 0.78 & $0.71,0.86$ & $<0.001$ \\
\hline \multicolumn{4}{|l|}{ Reason. Sample } \\
\hline VL-Compliance reinforcement & - & - & \\
\hline VL -6 months & 0.38 & $0.26,0.54$ & $<0.001$ \\
\hline VL -Routine & 0.35 & $0.26,0.48$ & $<0.001$ \\
\hline VL -Research & 1.04 & $0.66,1.64$ & 0.90 \\
\hline VL-Mother-child prevention & 1.04 & $0.16,8.22$ & $>0.90$ \\
\hline VL -Initiation & 0.53 & $0.36,0.78$ & 0.001 \\
\hline \multicolumn{4}{|l|}{ Under ARV treatment } \\
\hline No & - & - & \\
\hline Yes & 1.05 & $0.47,2.55$ & $>0.90$ \\
\hline \multicolumn{4}{|l|}{ Treatment line } \\
\hline $1^{\text {st }}$ line & - & - & \\
\hline $2^{\text {nd }}$ line & 1.43 & $1.08,1.88$ & 0.012 \\
\hline \multicolumn{4}{|l|}{ Treatment duration } \\
\hline$[0,1]$ & - & - & \\
\hline$(1,5]$ & 0.98 & $0.88,1.08$ & 0.60 \\
\hline$(5,11]$ & 0.85 & $0.75,0.95$ & 0.005 \\
\hline \multicolumn{4}{|l|}{ Age1 } \\
\hline$[0,20]$ & - & - & \\
\hline$(20,40]$ & 0.98 & $0.77,1.26$ & 0.90 \\
\hline$(40,60]$ & 1.03 & $0.70,1.52$ & 0.90 \\
\hline$(60,84]$ & 1.39 & $0.75,2.58$ & 0.30 \\
\hline
\end{tabular}


The objective of this study was to investigate the frequency and factors associated with viral load suppression in patients living with HIV/AIDS followed up in care sites in Conakry between January 2018 and June 2021.

The detection threshold was set at 390 copies $/ \mathrm{ml}$. This threshold is higher than the one used by some programmes, 200 copies/ml (12). Nevertheless, it is kept below that set by other national HIV/AIDS programmes and the WHO in the absence of any treatment, which is $<1000$ copies/ml $(13,14)$.

Data from more than ten thousand patients receiving viral load testing at the National Institute of Health Public showed that nearly seven out of ten people had a suppressed viral load. This rate is comparable to that reported by Diourra et al., $80 \%$ on 379 DBS samples(7). This rate is even lower than the UNAIDS and National AIDS and Hepatitis Control Programme target of $90 \%$ by $2020(15)$. This result also suggests that three out of ten patients could transmit the infection to their contacts even though they are all on antiretroviral treatment. Similar observations have been reported by other authors $(14,16)$.

In the univariate model of the data from this study, HIV-positive women with viral load at the National Public Health Laboratory were more likely to have VL suppression than men $[1.22(1.11 ; 1.34)<0.001]$. Kone $\mathrm{F}$ et al. showed similar proportions in their study in Côte d'Ivoire(5). This result also shows that men were more likely to have failed to suppress their viral load. It is known in the literature that women attend health services more than men for needs such as childbearing, bodily fragility, to diseases. A study conducted in Guinea on dropouts of patients on antiretroviral treatment showed that the proportion of dropouts was higher among men (2).

Multivariate analyses of the data also showed that treatment duration was independently associated with viral load suppression $[0.85(0.75 ; 0.95)<0.005]$. Similar observations have been reported by authors (17). Other authors have also reported similar observations in both sub-Saharan African countries and rich countries(18). This could be explained by the reduction in plasma viral load (RNA) over the years. This is contrary to the recommendations of $\mathrm{WHO}$ and indeed other agencies that patients on antiretroviral therapy should have viral load suppression after six months.

Patients on first-line ART were more likely to experience viral load suppression. This result is consistent with other authors' observations that the first-line regimen should be initiated in all HIV-positive people starting treatment $(14,19,20)$. As argued by some authors for the change from the former to the latter (21). However, the lack of genotyping data to know which non-deleting patients should switch treatment lines handicaps this decision by caregivers in Guinea. Similar observations have been noted by others (22). Unfortunately, this type of test is not yet available in Guinea. These results suggest the need to strengthen education and adherence, as only $1.6 \%$ of the patients in this study completed the VL as part of adherence strengthening.

Limitations and strengths 
This study, like many others, may have some limitations. These include the lack of clinical data to which the laboratory does not have access and would have facilitated the interpretation of the virological and therapeutic results. Another limitation of the study is that the data concern both the viral load at follow-up and initiation of treatment. However, to our knowledge, our study is one of the largest cohorts in the framework of the follow-up of PLHIV on antiretroviral treatment in Guinea. Even though the study covered an extended period, the patients all benefited from load measurement with the same technique and personnel over all these years.

\section{Conclusion}

The results of this study show a low suppression of virological load suppression among the population study. Duration of antiretroviral treatment, female gender, and advancing age were favourable to patients' viral load suppression. Continuation of this study by including genotyping data could refine the level of viral load suppression and manage those in virological failure.

\section{Declarations}

Acknowledgements

The authors would like to thank the authorities of the Faculty of Health Sciences and Techniques of the Gamal Abdel Nasser University of Conakry for their support in the continuing education of teachers. They thank the clinicians who made it possible to produce the CEA-PCMT and CERFIG study data for their financial and technical support. They also thank all the people who contributed to the realisation of this project: Dr Sidikida SIDIBE, Dr Aboubacar Sidiki MAGASSOUBA, Dr Almamy Toure, Dr Armel Tibaut Gnimagui and Mrs Abou Fontaine for their contribution in the statistical analyses and the person of the molecular biology unit of the National Public Health Laboratory for the laboratory analyses.

Availability of data and materials

The data supporting the conclusions of this study are available from the corresponding author, [AC], upon reasonable request.

Competing interests

The authors claim to have no conflict of interest

Authors' contributions

The authors

Alimou Camara designed the protocol, participated in the analysis and writhing of the manuscript. Then Penda Maladho Diallo and Mamadou Bobo Diallo helped with the manuscript 
Penda Maladho Diallo, Mamadou Bobo Diallo, Talla Nioké, Adama Cissé, Mamadou Alpha Sylla, Gobounet Lamah, Mamady Diakité, and Amadou Sadio Bah contributed to perform laboratory analysis for virogical load of HIV

Alimou Camara, Mamadou Boye Keita, Mamoudou Conde and Alpha Kabimet performed the data analysis, interpreted result and drafted the manuscript with the input from Kaba Kourouma, Robert Camara, Fode Banagaly Magassouba, Alioune Camara, and Abdoulaye Toure.

All others critically revised and approved the final manuscript.

Ethics approval and consent to participate

As the collection was done retrospectively on routine data, consent was not sought. However, each participant has a unique national code, and the staff in charge of collecting the samples maintained confidentiality. The study was approved by the research committee of the public health department of Gamal Abdel Nasser University in Conakry.

Consent for publication

All authors agree to the publication of the manuscript in this journal

Funding

Not applicable

\section{References}

1. Bvochora T, Satyanarayana S, Takarinda KC, Bara H, Chonzi P, Komtenza B, et al. Enhanced adherence counselling and viral load suppression in HIV seropositive patients with an initial high viral load in Harare, Zimbabwe: Operational issues. Mor O, editor. PLOS ONE. 2019 Feb 5;14(2):e0211326.

2. Touré A, Cissé D, Kadio Kjjo, Camara A, Traoré Fa, Delamou A, et al. Facteurs associés aux perdus de vue des patients sous traitement antirétroviral dans un centre de traitement ambulatoire du VIH à Conakry, Guinée. Rev DÉpidémiologie Santé Publique. 2018 Jul;66(4):273-9.

3. INSP. OPPE-ARA METTRE FIN AU VIH/SIDA PAR UN MEILLEUR SUIVI DES PATIENTS: ACCÉLÉRER L'ACCÈS ET L'UTILISATION DE LA CHARGE VIRALE [Internet]. 2019 Juillet p. 4. Available from:

https://www.insp-guinee.org/wp-content/uploads/2019/08/SOLTHIS_OPP-ERA_brochure-GUINEEA4_web.pdf

4. Institut National de la Statitique, Ministere du plan et du developpement Economique, Conakry, Guinee. Enquete Demographique et de Sante (EDS), 2018. 2019 Juillet p. 650. Report No.: V. 
5. Kone F, Toni T d'Aquin, Ouassa T, Menan H, Ebegui D, Diallo K, et al. Mesure de l'ARN VIH-1 et du taux de lymphocytes TCD4 dans le suivi du traitement antirétroviral de patients infectés par le VIH en Côte d'Ivoire. Int J Biol Chem Sci. 2019 Sep 6;13(3):1343.

6. ONUSIDA. Rapport mondial d'avancement sur la lutte contre le sida 2019, en Guinee [Internet]. ONUSIDA-GUINEE; 2019 p. 47. Available from:

https://www.unaids.org/sites/default/files/country/documents/GIN_2019_countryreport.pdf

7. Diouara AAM, Ndiaye HD, Guindo I, Bangoura N, Cissé M, Edmond T, et al. Antiretroviral treatment outcome in HIV-1-infected patients routinely followed up in capital cities and remote areas of Senegal, Mali and Guinea-Conakry. J Int AIDS Soc. 2014 Jan;17(1):19315.

8. Abdoulaye Wotem Somparé. La politique et les pratiques de santé en Guinée à l'épreuve de l'épidémie d'Ebola: le cas de la ville de Conakry in Lien Social et Politiques, n. 78, 2017. Erudit. 2017;19.

9. CNLS. Cadre Stratégique National de Lutte les IST/VIH/Sida 2013-2017 [Internet]. 2012 p. 97. Available from: https://www.childrenandaids.org/sites/default/files/201805/Guinea_Nat\%20Stat\%20Framework\%20HIV_2013-2017\%20fr.pdf

10. WHO. Normes et protocoles de prise en charge de l'infection par le VIH chez l'adulte et l'enfant en GUINEE [Internet]. 2005. Available from: https://www.who.int/hiv/pub/guidelines/guinea_art.pdf

11. Elyse Poitras et Alain Houde. La PCR en temps réel: principes et applications. Reviews in Biology and BiotechnologyBy The Moroccan Society of Biology in Canada. 2002 Dec 2;11.

12. Arkell C., Perez E. Le traitement du VIH et la charge virale indétectable pour prévenir la transmission du VIH. 2021; Available from: https://www.catie.ca/fr/feuillets-info/transmission/vih-charge-viraletraitement-transmission-sexuelle

13. Drain PK, Dorward J, Bender A, Lillis L, Marinucci F, Sacks J, et al. Point-of-Care HIV Viral Load Testing: an Essential Tool for a Sustainable Global HIV/AIDS Response. Clin Microbiol Rev [Internet]. 2019 Jun 19 [cited 2021 Jul 16];32(3). Available from: https://journals.asm.org/doi/10.1128/CMR.0009718

14. Eisinger RW, Dieffenbach CW, Fauci AS. HIV Viral Load and Transmissibility of HIV Infection: Undetectable Equals Untransmittable. JAMA. 2019 Feb 5;321(5):451.

15. Kitchen PJ, Bärnighausen K, Dube L, Mnisi Z, Dlamini-Nqeketo S, Johnson CC, et al. Expansion of HIV testing in Eswatini: stakeholder perspectives on reaching the first 90. Afr J AIDS Res. $2020 \mathrm{Jul}$ 2;19(3):186-97.

16. Ba S, Dia Badiane NM, Hawes S, Deguenonvo LF, Sall F, Ndour CT, et al. Infection à VIH-2 au Sénégal: échecs virologiques et résistances aux antirétroviraux (ARV). Pan Afr Med J [Internet]. 2019 
[cited 2021 Aug 21];33. Available from: http://www.panafrican-medjournal.com/content/article/33/222/full/

17. Kiweewa F, Esber A, Musingye E, Reed D, Crowell TA, Cham F, et al. HIV virologic failure and its predictors among HIV-infected adults on antiretroviral therapy in the African Cohort Study. MenéndezArias L, editor. PLOS ONE. 2019 Feb 5;14(2):e0211344.

18. Nosyk B, Montaner JSG, Colley G, Lima VD, Chan K, Heath K, et al. The cascade of HIV care in British Columbia, Canada, 1996-2011: a population-based retrospective cohort study. Lancet Infect Dis. 2014 Jan;14(1):40-9.

19. Ndembi N, Murtala-Ibrahim F, Tola M, Jumare J, Aliyu A, Alabi P, et al. Predictors of first-line antiretroviral therapy failure among adults and adolescents living with HIV/AIDS in a large prevention and treatment program in Nigeria. AIDS Res Ther. 2020 Dec;17(1):64.

20. Ssempijja V, Nakigozi G, Chang L, Gray R, Wawer M, Ndyanabo A, et al. Rates of switching to second-line antiretroviral therapy and impact of delayed switching on immunologic, virologic, and mortality outcomes among HIV-infected adults with virologic failure in Rakai, Uganda. BMC Infect Dis. 2017 Dec;17(1):582.

21. Beaudrap PD, Thiam M, Diouf A, Toure-Kane C, Ngom-Guèye NF, Mboup S, et al. Risk of Virological Failure and Drug Resistance During First and Second-Line Antiretroviral Therapy in a 10-Year Cohort in Senegal: Results From the ANRS 1215 Cohort. J Acquir Immune Defic Syndr. 2013;62(4):7.

22. Ford N, Orrell C, Shubber Z, Apollo T, Vojnov L. HIV viral resuppression following an elevated viral load: a systematic review and meta-analysis. J Int AIDS Soc [Internet]. 2019 Nov [cited $2021 \mathrm{Jul}$ 14];22(11). Available from: https://onlinelibrary.wiley.com/doi/10.1002/jia2.25415

\section{Figures}




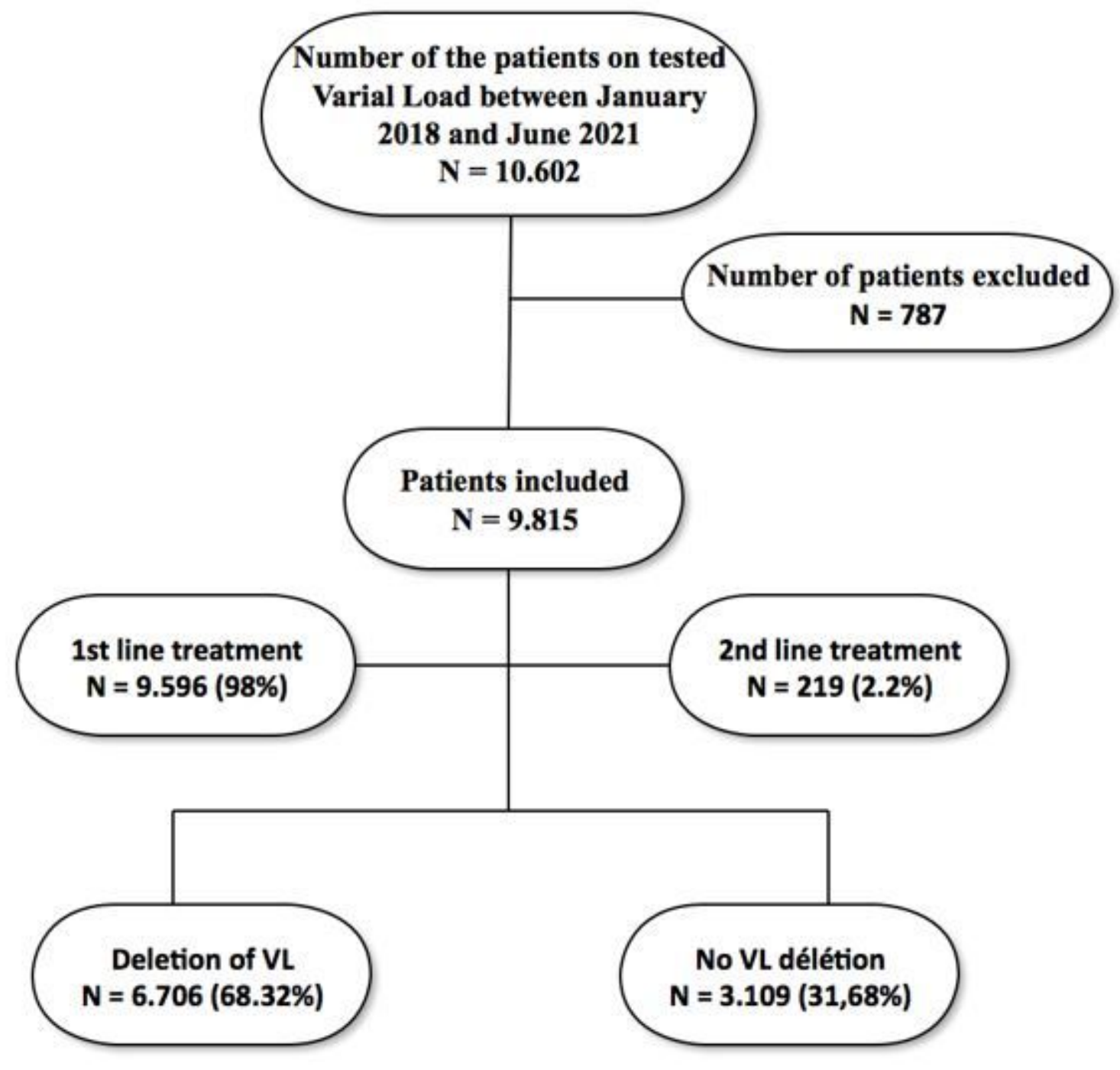

Figure 1

Flow chart summarising all the data from the study Description Data from ten thousand six two patients with viral loads between January 2018 and June 2021 were extracted, from which we excluded 782 whose data were incomplete. We therefore retained 9815 viral load data. Of these, 9596 were on therapeutic line 1 and the rest on line 2. A total of 6706 patients had suppressed viral loads compared to 3109 patients with detectable viral loads. 